\title{
JOURNAL OF AFRIGAN LAW
}

\section{Volume 41 Number 21997}

\section{Contents}

\section{Abstracts}

Ethnicity and constitutionalism in contemporary Ethiopia Jon Abbink 159

The evolution of medical malpractice law in South Africa Neil van Dokkum 175

When crime crosses borders: a Southern African $\quad$ Daniel D. 192 perspective

Ntanda Nsereko

The law and practice of customary arbitration in Nigeria: Virtus Chitoo Igbokwe 201 Agu v. Ikewibe and applicable law issues revisited

\section{Case notes}

Developments in the field of criminal justice

G. N. K.

administration in Nigeria: Saro-Wiwa in review

Vukor-Quarshie

The right to speedy trial in Namibia and South Africa

Derek Obadina

Statute Note

The Petroleum (Amendment) Decree, 1996, of Nigeria

Recent developments

Making the final constitution in South Africa

New legislation on legal aid in Zimbabwe

Expanding the role of the Ombudsman in Zimbabwe

Establishment of an Independent Complaints Directorate in South Africa

Liberalizing the abortion law in South Africa

Seychelles passes anti money laundering legislation

International developments

Roundtable of heads of government of Commonwealth Africa on democracy and good governance in Africa

African Regional Industrial Property Organisation (ARIPO) and the Banjul Protocol 